\title{
Feet and fertility in the healing temples: a symbolic communication system between gods and men?
}

\author{
Marco Cilione, ${ }^{1}$ Silvia Marinozzi, ${ }^{2}$ Valentina Gazzaniga'
}

${ }^{1}$ Unit of History of Medicine and Bioethics, Department of Medico-Surgical Sciences and Biotechnologies, Sapienza University of Rome, Rome, Italy ${ }^{2}$ Unit of History of Medicine and Bioethics, Department of Molecular Medicine, Sapienza University of Rome, Rome, Italy

Correspondence to Dr Silvia Marinozzi, Unit of History of Medicine and Bioethics, Department of

Molecular Medicine, Sapienza University of Rome, Rome 00185, Italy;

silvia.marinozzi@uniroma1.it

Received 26 December 2017 Revised 22 March 2018 Accepted 1 May 2018

Check for updates

To cite: Cilione $M$, Marinozzi S, Gazzaniga V. Med Humanit Epub ahead of print: [please include Day Month Year]. doi:10.1136/ medhum-2017-011439

\section{ABSTRACT}

Anatomical ex-votos of feet have always been interpreted as representing the unhealthy part of the body for which patients were asking healing. However, according to the archaeological data and literary sources, another interpretation is also possible: the purpose of this article is to focus on the strong relationship between feet and fertility in the ancient world by crossreferencing the available archaeological evidence with the scientific data relating to this topic. That shed light on an important aspect of the Healing Temples in Greek and Roman medicine.

\section{INTRODUCTION}

Anatomical ex-votos continue to remain only a partially resolved archaeological and medico-historical question. These terracottas, which represent parts of the human body derive from different geographical areas and varying chronological ancient time-scales (Greece, IV century BC up to Late Antiquity; Etruria, Rome and CentralSouthern Italy, IV century BC up to I century BC). They have been viewed by historical and archaeological tradition in several various ways. According to traditional interpretation, they were intended to be objects of worship, offered up to the gods in healing sanctuaries indicating either the nature of the illness or the bodily dysfunction for which the prayer was a cry for help and healing. ${ }^{1-12}$ From this perspective, the offer of an ex-voto also meant the redemption of a vow, a physical representation of the patient's gratitude. The image of a 'commercial pact' between men and gods, a mechanism to compel the gods to respond to human requests and for humans to also remember the power of the gods. ${ }^{13}$ Generally, they were intended to be signals. But, signals of what?

Since 2000, a revival of scientific interest in the significance of these artefacts has produced some significant contributions which have tried to shed light on the meaning of anatomical votives in different contexts. ${ }^{14-17}$ Recent studies have interpreted them as a means of evoking the condition of well-being and completeness of a healthy life 'outside the temple'; as depictions of the patients' feelings regarding a perceived 'disintegration' of their ill bodies ${ }^{18} 19$ or, more generally, as a way 'to communicate a variety of messages to the god'. ${ }^{18}$ Some authors suggest that votives do not always represent a request for healing, ${ }^{20}$ thus opening the way to new possibilities for their interpretation, meaning that aetiopathology might cease to be the main or favoured criterion for their decoding.
Evidence for the possibility of displaying ex-votos together and in groups ${ }^{21}$ could also explain why, in chronological homogeneous contexts, groups of sanctuaries are rich in a certain type of votive (ie, feet, knees, legs, arms and so on) while others in terracotta reproduce other parts of the human body (ie, sexual organs, wombs, breasts and so on). ${ }^{22}$

Thus, recent historiography is more generally trying to reinterpret anatomical votives not as mere visual representations of affected organs and limbs, but as tools of a complex symbolic communication system between men and gods: from this perspective, they should be viewed as conventional signs, the choice of which depends on a multitude of factors (eg, the common votive practices in each sanctuary, the type of divinity to which the gifts are offered, the availability of specific anatomical typologies in the workshops surrounding the temples, the financial resources of the devotees, the manner in which the patients experienced their bodily symptoms-and last, but not least, the different levels of symbolic language employed) according to the stratified cultural dimensions of the Ancient Mediterranean cultures. With regard to specific types of ex-voto, the interpretation would seem simple: uteri and male genital organs clearly allude to the constant concern, typical of ancient cultures, of having children and guaranteeing the citizens a social role through the biological processes of paternity and maternity. But what about other types of votives, far less indicative than those related to direct fertility requests?

In particular, Greek and Etrusco-Roman-Campanian ex-votos seem to be comprehensible only through a combined approach based on the use of archaeological data, written medical, literary and cultural sources-paths which, strange though it may seem, have not been simultaneously cross-referenced by earlier historiography until now.

Medical narratives, already limited even when verbally explicit, ${ }^{23}$ become difficult to interpret when the period that separates us from the stories of illness is extended and when their communication system is a non-verbal one. Ex-votos, which narrative voice extends over a long-term period and on different geographical and cultural territories, ${ }^{24}$ provide an interesting example of the polysemy of meanings medical objects can convey. Ex-votos may be perceived within a traditional and 'reductionist' vision (as simple indicators of the body parts for which healing intervention is required), but we believe a more effective interpretation is that of a metaphorical communication system of complicated medical concepts. ${ }^{25}$ This is the case regarding 


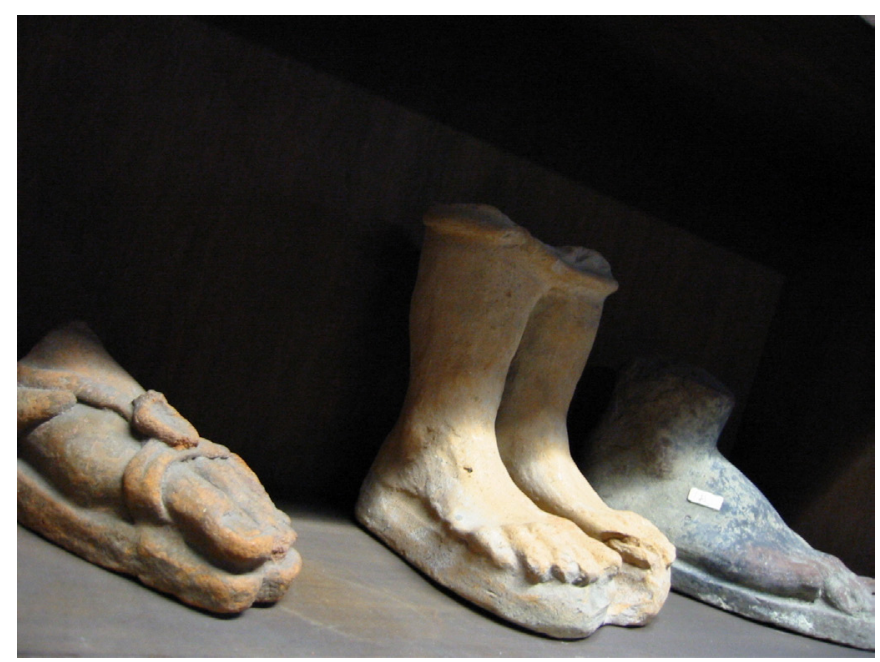

Figure 1 Votives in the Museum of the History of Medicine, Sapienza University of Rome.

fertility, which abnormalities are, in ancient cultures, a pathology and at the same time, a social limitation.

\section{ARCHAEOLOGICAL FEET IN ANCIENT HEALING CULTS}

Votives from the sanctuary at Asklepius in Corinth, dating from between the end of the $\mathrm{V}$ and the beginning of IV century BC, are the first Greek documentation that we have at our disposal, homogeneous by type and dating, testifying to the use of anatomical terracottas reproducing human body parts: objects which were cheap and readily available, light and manageable despite their often large dimensions, destined to be hung on the walls of the temple. ${ }^{26}{ }^{27}$ From the seven deposits of the Asklepieion a significantly high number of ex-votos still survive in good condition, almost all of which are reproductions of legs and arms. Among these, there are a large number of feet (20 in total, probably originally part of a more complete leg structure which were partially destroyed and lost; 9 including the lower part of the leg to the knee; 5 feet with their original painted top; 10 complete legs) as well as many fragments, leading us to assume a number of original pieces at least three or four times greater than the surviving ones (figure 1). Among the other body parts, there is a predominance of hands, breasts and male genitalia, suggesting a cultural context with strong ties to the issues of fertility and reproduction. ${ }^{18}$ The hand as a symbol of fertility has been proposed by R B Onians, who also cited the practice of striking the hands of women with a leather knout, according to the use of Luperci; in the cult of Isis, bronze hands were offered as a prayer for a save delivery. ${ }^{28}$ These constitute an interesting group of votive objects: in primis, because they are made of terracotta. In other Greek sanctuaries (such as, for instance, the Asklepieion in Athens, where ancient records list 1347 ex-votos dating from IV to III century BC) ${ }^{29} 30$ votive objects were fashioned from small marble steles or metal objects. Some historians propose that the oldest ex-votos in Corinth were also probably made of metal alloys. ${ }^{18}$

Moreover, Corinthian ex-votos seem to be the probable models for Etrusco-Latial-Campanian ones: in fact, Etruscan ex-votos, although far more numerous, replicate the same structure and form as the Corinthian ex-votos. They were shaped in terracotta, fully moulded, made on an 'industrial scale' and probably sold for little money. Some authors think that ELC anatomical votives derive directly from a 'Corinthian connection', which could have been established through maritime commerce connecting the Etruscan port of Tarquinia-Gravisca to Corinth. ${ }^{31} 32$ Greek originals could then be redesigned and reworked thanks to the skill of the workers of Magna Grecia, masterfully moulding terracotta to produce antefissae. Other authors, however, argue that ELC types arrived directly in South Etruria from Magna Grecia, spreading in agricultural contexts, where popular fertility cults were diffused, and then expanding again to Southern Italy (Paestum and Lucera). ${ }^{33}$

In any case, Greek models enjoyed an extraordinary success in ancient Italy; a recent catalogue calculated 7672 anatomical ex-votos in Etruscan territories alone, compared with the 515 attributed to the Greek world. ${ }^{33}$

Contrary to what is commonly believed, Etrusco-Italic and Roman ex-votos are not related to the cult of Asklepius, introduced to Rome in 293 BC: ${ }^{34} 35$ their donation seems to be linked rather to other deities, most of them feminine. Though sometimes we can establish who these deities are (Demetra/ Ceres, Kore, Artemis/Diana, Juno, Minerva-or Vei and Uni, in Etruscan contexts), more often their precise identification remains a mystery. ${ }^{36}$ In any case, archaeological studies generally reveal a close connection between anatomical votives and fertility and childbirth cults-and not solely confined to healing ones; this hypothesis is supported by the predominance of female anatomical votives in Hellenistic Central Italy and by the high number of reproductive organs attested, especially in Thyrrenian territories, such as wombs, penises and breasts.

Archaeology has fully analysed these votives, computing and classifying them by means of detailed quantitative analysis; ${ }^{5}$ the large quantity of numeric data at our disposal reveals a very high number of clay feet (second only in quantity to the occurrence of reproductive organs), either isolated feet alone or feet connected to the lower parts of legs up to the knee (figure 2). Some of these are bare, while some are depicted with sandals or slippers; some are life-sized, others clearly represent children's limbs; they may be standing or walking. Some bear marks of deformity or swelling but, more frequently, the feet seem normal. This datum is perfectly consistent with archaeological evidence from different cultural roman contexts, such as the

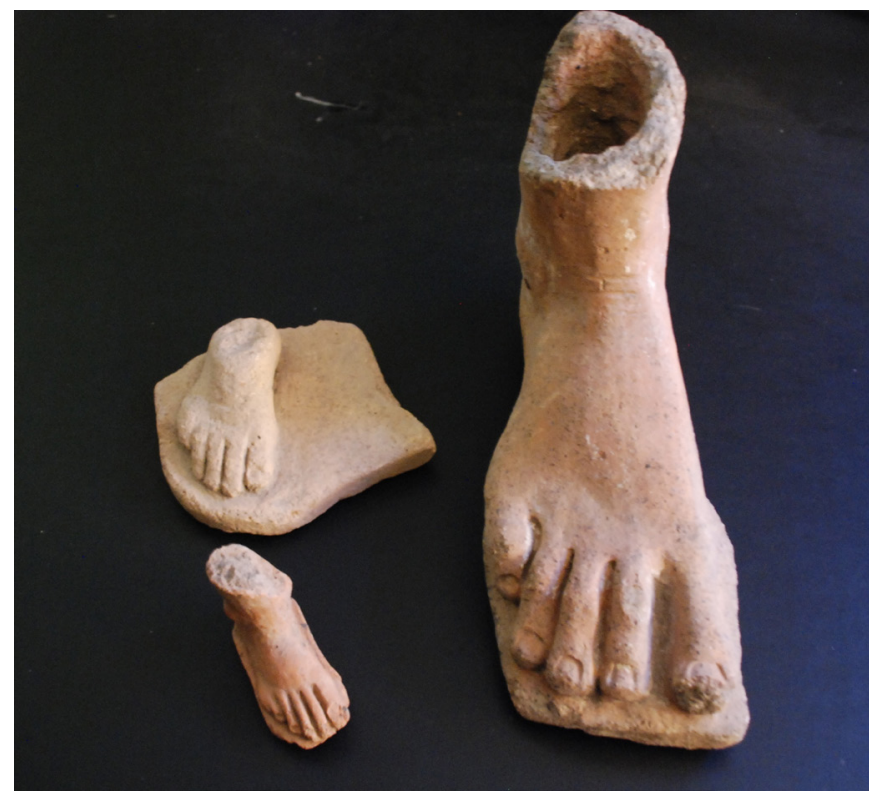

Figure 2 Votives in the Museum of the History of Medicine, Sapienza University of Rome. 


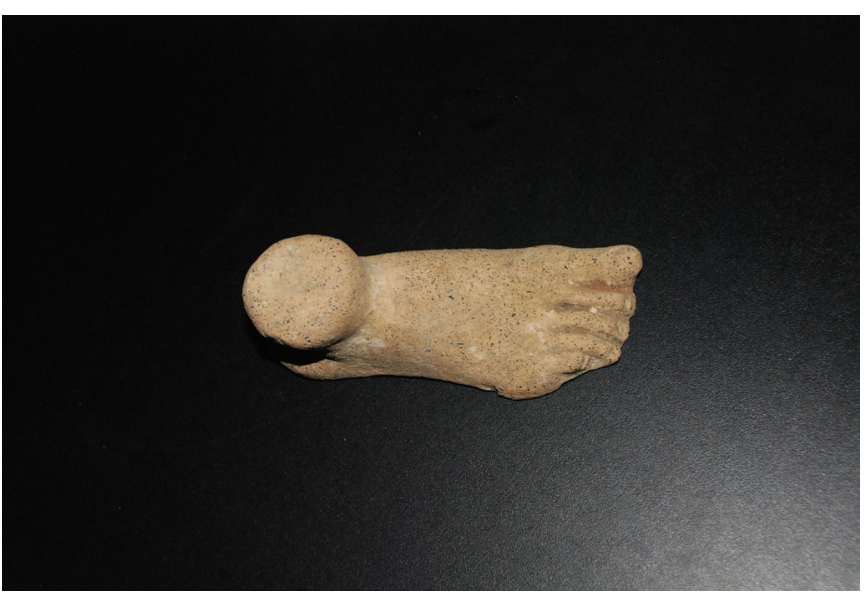

Figure 3 Votives in the Museum of the History of Medicine, Sapienza University of Rome.

worship sites in France, clearly testifying to the importance similarly attributed to the limbs, ankles and feet during the GalloRoman Age. ${ }^{3738}$ Interestingly, the percentage of their proportion also mirrors the Corinthian findings. ${ }^{39}$ By way of example, we can furnish some numerical data concerning anatomical votives from archaeological contexts near Rome: The Thirteenth Altars in Lavinium, a federal ancient sanctuarium later associated with the cult of Ceres (V-III century BC), contained 207 lower limbs (in comparison with over a hundred upper limbs and a few other body parts); ${ }^{41}$ at Ponte di Nona, a Republican rural healing sanctuary devoted to an unidentified deity, 8400 anatomical pieces have been recorded, 6000 of which consist of feet and hands; ${ }^{42}$ from the temple of Asclepius in Fregellae, dating from the II century BC, a total of about 4000 votives of which 1654 are feet; at Nemi, in a sacred area frequented from V century BC up to the Late Imperial Age, where the temple devoted to Diana, goddess protecting fertility and childbirth, revealed a very low percentage of anatomical votives dealing with pregnancy or female disorders in comparison to a strong prevalence for feet and legs. ${ }^{43}$ Etruscan temples (ie, Tarquinia, Veii, Ara della Regina, Vulci, Punta della Vipera, Tessennano), although not entirely consistent in their dating, bear witness to similar numerical proportions; ${ }^{45-47}$ the same is true in Southern Italy, for example, at the ancient site of Cuma, dating from the IV-II century BC, where a healing cult with components of fertility has been attested by the presence of anatomical votives with a strong prevalence for hands and feet, which match the data from Etruscan and Central-Italian deposits very well. ${ }^{48-50}$

This strong presence of feet, already described in literature, ${ }^{45}$ has often been explained according to a 'medical reductionism' as nothing more than requests for healthy feet and limbs in societies in which an excellent walking ability was required for a people often wearing unhealthy footwear. Unfortunately, paleopathological Etruscan and Roman Republican evidence is too scarce to illustrate the real occurrence of feet diseases between the IV and I century BC and thus possibly to justify the very frequent occurrence of feet votives. The excavated necropolis of the Roman Republican era are few and the surviving remains are generally cremated. More anthropological data could come from the Imperial Age. Ex-votos which almost never depict pathological conditions lead to another recurring interpretation, according to which feet, knees and legs could be thanksgivings for a safe and successful journey. ${ }^{51}$
These historic-medical and archaeological explanations leave some questions unresolved: is the idea of 'safe travel' sufficient to explain why almost all the feet seem to be normal, non-pathological samples? Moreover, the vexed question of why some feet are depicted with shoes and others without, still lacks a satisfactory answer even today. The same is true in the observation of the inverse relationship between the presence of feet and the corresponding absence (or scarce presence) of other bodily parts, especially penises, wombs and breasts. While feet and legs are numerous, sexual organs are rare: this situation is well documented for central Italy, where worshippers favoured the representation of limbs, feet and hands, rather than the sexual parts more common in the Thyrrenian area. ${ }^{52}$ The idea that the populations of Central Italy, living in mountain areas (exactly as Corinthian people), were more prone to foot diseases appears too simplistic and fails to explain the almost total absence in Apennine Italy of anatomical votives representing reproductive organs.

In all likelihood, no single interpretation is valid; a more complex hypothesis might promote a better understanding of the cultural meaning that votive feet had in different ancient cultures and in diverse cultural ways of thinking. Our proposal is founded on the idea that in all cultures, images are a polysemic and 'migrating' way to communicate ideas that are slowly and constantly changing, while at the same time remaining formally the same. Consequently, a new question arises: if it is true that, in ancient Mediterranean cultures, the votum pro valetudine had a much broader significance than that we attribute today to the concept of health and wellness, ${ }^{53} 54$ is it possible that the offering of feet or genitalia was intended as a synonymous act? In other words, is it possible that the offering of feet to the gods served the same purpose as the offering of penises or wombs?

\section{FEET IN LITERARY AND MEDICAL SOURCES}

The landscape which emerges from the analysis of the archaeological documentation pertinent to the anatomical votives of feet and footprints, in their possible association with fertility, is confirmed by some literary passages of poetical, anecdotic and medico-scientific nature, ${ }^{55}$ which seem to make more sense when placed in the material culture and in the schemes of the civilisation to which the ex-votos examined belong (figure 3). In these passages, feet become the parameters of recognition for the father-son descent, because the ancient world identified them with the source of the seed and of the vital soul. A passage ${ }^{28}$ from Fulgentius's Mitologiarum libri explains the allegorical reasons for Achilles's heel vulnerability, also providing an interesting digression of medical nature: '[...] the veins which are in the heel connect with the faculties of the kidneys, thighs, and sex organs, [...]. Orpheus himself demonstrates that this [the heel] is the chief seat of lust, $[\ldots]$ ]. ${ }^{56}$ According to Fulgentius's words, ${ }^{57}$ the heel is clearly meant to be one of the places in which the human seed is located. The system of ducts and veins mentioned by the author seems to involve the entire body in the production of the generative seed in accordance with the pangenetic theory for the origin of the seed which associates the venous system with the reproductive system. The pangenetic or ematogenetic theory finds ancient and important supporters in Anaxagoras, Diogenes of Apollonia and Democritus, in opposition to the encephalo-myelogenic theory ${ }^{58}$ supported by the pythagorean Alcmaeon and Hippon of Rhegium. ${ }^{59}$

The literary witnesses and the anthropological-cultural traditions of the ancient world demonstrate that the parts of the body in which it is possible to recognise the father-son descent such as 


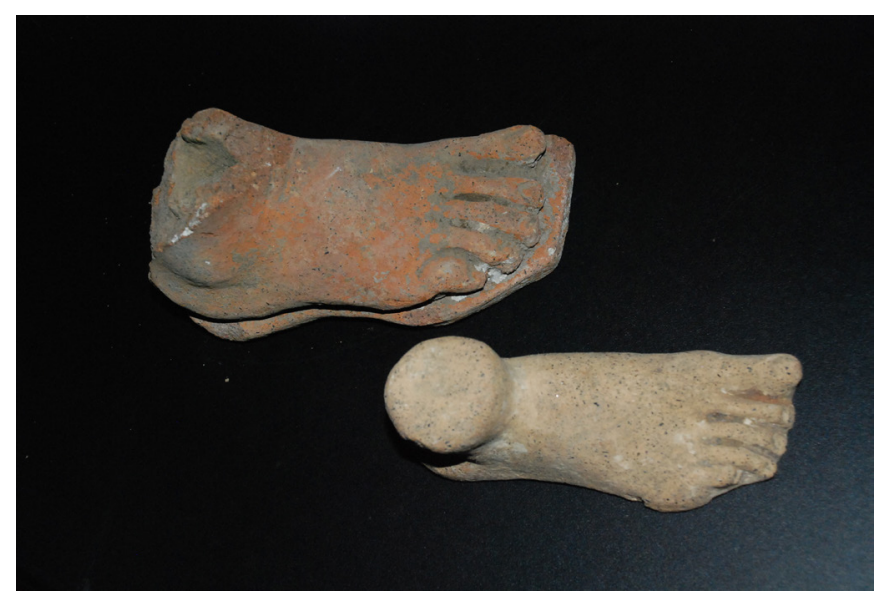

Figure 4 Votives in the Museum of the History of Medicine, Sapienza University of Rome.

the head, the hands, the knees and the feet are exactly the same where the generative seed originates or passes through. When Telemachus goes to Menelaus's court in search of his father and Helen asks her husband about the foreigner's identity, guessing he could be Odysseus's son due to the likeness between the young man and the King of Ithaca, Menelaus confirms his wife's intuition because the feet, hands, head and hair of Telemachus look like those of his father. ${ }^{60}$ The scholia graeca in Od. IV 149 explains, as regards the feet, that 'the likeness of the bodies is mainly revealed by the extremities and the sight'. ${ }^{61}$

Now, according to the pangenetic theory, the seed is distilled from all the parts of the body and flows towards the genitals through blood circulation. Diogenes of Apollonia ${ }^{62}$ meticulously describes the complex venous system which links up the extremities of the human body and adds:

'The more dense blood is absorbed by fleshes; the exceeding one, instead, moves to these places (testicle and uterus) and becomes light, warm and foamy'. ${ }^{63-65}$

As a matter of fact, the seed, as blood foam, moving through all parts of the body, retains their memory and, before flowing to the genitals, displays that memory exactly where it gathers most, that is in the extremities, which are destined to reproduce their very likeness.

As Aristotle affirms, ${ }^{66}$ in eunuchs the deposition of the seed in the legs is due to their sexual withdrawal and the natural movement of fluids from the top to the bottom. As a matter of fact, the association legs-feet-generative seed seems to be confirmed by the practice of binding the legs to facilitate procreation and, on the other hand, by the connection between lameness and sterility. Some studies ${ }^{28} 67$ have already underlined the relationship between knees and the generative seed based on the ancient custom of acknowledging the son by sitting him on his father's knees. ${ }^{68-70}$

As regards the connection between lameness and sterility or sexual anomalies, myth too provides us with a key to its interpretation. Hephaestus, indeed, born lame due to an unsuccessful abortion, lavishes his compromised creative energy on metallurgy, while his wife Aphrodite, whose name seems to have its origin in the blood foam of Diogenes of Apollonia, neglects him in favour of Ares: his progeny is therefore scarce and even deformed. ${ }^{71}$ The Amazons lame their newborn male babies by dislocating both their knee and hip to prevent riots and in order to use them for manual labour ${ }^{72}$ and perhaps also to compromise their fertility as well. Laius punctures Oedipus's feet before exposing him, partly also to irreparably disfigure one of the places of the father-son likeness or to unconsciously cancel the generative opportunity of the incestuous bond between him and his mother, as if Oedipus's swollen feet prefigured the miserable progeny he would give birth to.

However, the most significant confirmation of the relationship between the feet and procreation comes from Greek tragedy. M Untersteiner, in his commentary to Aeschylus's Choephors, associates Menelaus's identification of Telemachus as Odysseus's son with the scene of Electra's recognition. ${ }^{73}$ After arriving at her father's grave to pour libations, Electra finds a lock of hair and some footprints. The young princess recognises the relationship of consanguinity between herself and the mysterious foreigner by verifying the proportion between her feet and the footprints left by her brother Orestes. The girl speaks specifically of the prints of the heel and the tendons, as does Fulgentius.

Due to their characteristic conformation, the feet reveal a person's belonging to a certain line of descent. In this case, Aeschylus emphasises the similarity of the feet on the father's side to strengthen Anaxagoras's theory that attributes embryogenetic faculties only to the male seed, reducing woman to a mere container. In Aeschylus, the foot, as a place of recognition, allows for a further confirmation of the hypothesis that it also represents the seat of the generative seed.

Moreover, the saga of the Atreides seems to confirm our hypothesis. In one version of the myth Thyestes realises he has eaten his sons because his brother Atreus shows him their heads, hands and feet, which had been previously cut off; in another version, Atreus first chops the hands and feet of the children to prevent his father from recognising them. Moreover, in the Odyssey, when Odysseus, disguised as a beggar, is identified first by Penelope and later by the nurse, it is thanks to the formation of his feet. ${ }^{74} 75$ Pindar, too, talking of the athletic qualities of Ippocleas in terms of his inheritance from his father Fricias, an Olympic champion, uses the metaphor of the footprints. ${ }^{76}$

\section{CONCLUSION}

The recently growing attention paid by the medical communities to the Medical Humanities ${ }^{77}$ led to the development of an awareness that, as medicine and therapy respond to the cultural models that express them, these models, in the same way-as a cultural heritage of specific social groups - are themselves indissoluble parts of medical care and therapy. From this perspective, the contribution of the history of medicine can be crucial in the attempt to reconstruct the human dimension of care. ${ }^{78}$ The central object of the Medical Humanities is the history of the relationship between healer and patient and the emotional contents conveyed by this relationship. As regards ancient medical history, historians only rarely have direct sources concerning patients' experience of illness: medical texts testify only to the part played by physicians. Due to the limitation of sources, objects and archaeological findings can be used to interpret and complete those rare patients' narratives. In particular, ex-votos can be seen as a continuous dialogue with the gods of healingemphasising the human experience of suffering, expressing the fear of the disintegration of the healthy body, articulating the need to request help and stressing the expectations for the fertility of ancient populations.

In fact, when cross-referenced with the archaeological sources, the literary witnesses, in harmony with those scientific and medical, allows us to concur that the foot is the place through which the generative seed passes or where it sits because it or its prints allows for the recognition of the phenotypic traits belonging to the genetic inheritance. Thus, since the anatomical votives of feet and footprints are far more numerous than the ex-votos of genitals and are often 
associated with the uterus and placed in sanctuaries of fertility, they can rightly express either the representation of fertility or the request for perpetuating the likeness in a legitimate progeny. Consequently, it is no surprise that the foot, if intended as a symbol of fertility, was one of the most common ex-votos in the sanctuary (figure 4). The ancient world had always to face the risk of oliganthropia ${ }^{79}$ due to wars, diseases ${ }^{80}$ and high child mortality rate. For this reason, the request for fertility in terms of increment or healing was a private desire and a political need of the cities to ensure their survival. ${ }^{81} 82$

Contributors The idea was conceived by VG, director of the research; MC performed a philological analysis of the ancient literary sources and prepared the manuscript; SM carried out data from ancient Roman ex-votos and guarantees the originality of the work.

Funding The authors have not declared a specific grant for this research from any funding agency in the public, commercial or not-for-profit sectors.

Competing interests None declared.

Patient consent Not required.

Provenance and peer review Not commissioned; externally peer reviewed.

Author note The submitted article is a step of the PRIN (Research National Project) 2015 on the lifestyle in ancient Rome and the relationship between culture, diseases and medicine.

(c) Article author(s) (or their employer(s) unless otherwise stated in the text of the article) 2018. All rights reserved. No commercial use is permitted unless otherwise expressly granted.

\section{REFERENCES}

1 Pazzini A. II significato degli ex voto e il concetto di divinità guaritrice. Rendicont della Reale Accademia dei Lincei, Classe di Scienze morali, storiche e filologiche 1935; $\mathrm{VI}, 9: 42-79$.

2 Tabanelli M. Gli ex-voto poliviscerali etruschi e romani. Firenze: Olschki, 1964.

3 Decouflé P. La notion d'ex-voto anatomique chez les Etrusco-Romains. Bruxelles: Collection Latomus, 1964.

4 Fenelli M. Contributo per lo studio del votivo anatomico. Archeologia Classica 1975;27:206-52.

5 Comella A. Tipologia e diffusione dei complessi votivi in Italia in epoca medio- e tardo-repubblicana. Contributo alla storia dell'artigianato antico. Mélange de l'École Française de Rome Antiquité 1981;93 2:717-803. (henceforth MEFRA).

6 Comella A. Riflessi del culto di Asclepio sulla religiosità etrusco-laziale e campana di epoca medio- e tardo-repubblicana. Annali della Facoltà di Lettere e Filosofia di Perugia 1982-83;20:217-43.

7 Charlier P. Nouvelles hypothèses concernant la représentation des utérus dans les ex-voto etrusco-romains. Anatomie et histoire de l'art. Ocnus-Quaderni della Scuola di Specializzazione in Beni Archeologici 2000;8:33-46.

8 Comella A. II messaggio delle offerte dei santuari etrusco-italici di periodo medio-e tardo-repubblicano. In: Comella A, Mele S, eds. Depositi votivi e culti dell'Italia antica dall'età arcaica a quella tardo-repubblicana. Bari: Edipuglia, 2005:47-59.

9 Oberhelman SB. Anatomical votive reliefs as evidence for specialization at healing sanctuaries in the Ancient Mediterranean World. Athens Journal of Health 2014 1/1:47-62.

10 Michaelides D. 'The Anatomical Ex-votos of Hellenistic and Roman Cyprus. Michaelides D, ed. Medicine and Healing in the Ancient Mediterranean World. Oxford and Philadelphia: Oxbow Books, 2014:30-40.

11 De Cazanove O. Per la datazione degli ex-voto anatomici d'Italia. In: Burgerts GJ, Stek T, eds. The impact on cult places and religion in Italy. New approaches to change and continuity. London: Institute of Classical Studies, School of Advanced Study, University of London, 2015:29-66.

12 Draycott J, Graham EJ, eds. Bodies of evidence. Ancient anatomical votives past, present and future. London and New York: Routledge, 2017.

13 Schoerner G. Anatomical ex-votos. In: Raja R, Ruepke J, eds. A Companion to the Archaeology of Religion in the Ancient World. Malden, Oxford: Wiley Blackwell, 2015:397-412.

14 Bispham E, Smith C. Religion in Archaic and republican Italy-Evidence and Experience. Chicago-London: Fitzroy Dearborn Pub, 2000:76-8.

15 Osborne R. ed. The object of dedication. World Archaeology, 2004:36/1

16 De Cazanove O. Oggetti muti? Le iscrizioni degli ex voto anatomici nel mondo romano. In: Bodel J, Kajava M, eds. Religious dedications in the Greco-Roman World. Rome: Institutum Romanum Finlandiae, 2009:355-71.

17 De Hemmer Gudme AK. Before the God in this place for good remembrance. Berlin: De Gruyter, 2013.

18 Hughes J. Fragmentation as metaphor in the classical healing sanctuary. Social History of Medicine 2008;21/2:217-36. henceforth SHM.
19 Ferris I. Roman Britain through its Objects. Stroud: Amberley Publishing, 2012:70. chapt. 3, note 70

20 Glinister F. Reconsidering religious Romanization. In: Schultz CE, Harvey PB, eds. Religion in Republican Italy: Yale Classical Studies, 2006:33:92. (henceforth YCS).

21 Salapata G. The more the better? Votive offerings in sets. Australasian Society for Classical Studies 2011:32:2.

22 Scopacasa R. Moulding cultural change: a contextual approach to anatomical votive terracottas in Central Italy, Fourth- Second Centuries BC. Pap Br Sch Rome 2015:83:1-27

23 McKechnie CC. Anxieties of communication: the limits of narrative in the medical humanities. Med Humanit 2014:40:119-24.

24 Pon L, Amatruda JF. Breast cancer between faith and medicine: the Peres Maldonado ex-voto. Med Humanit 2010:36:112-4.

25 Neilson S. Pain as metaphor: metaphor and medicine. Med Humanit 2016;42:3-10

26 Straten FT. Gift for the Gods. Vernel HS, ed. Faith. hope, and worship: aspects of religious mentality in the Ancient World Leiden Brill Archive, 1981:65-151.

27 Forsén B. Griechischen Gliederweihungen ihrer Religions und Sozialgeschichtlichen Bedeutung. Helsinki: Finnish School of Athens, 1996.

28 Onians RB. The Origins of European thought about the body, the mind, the soul, the world, time, and fate. Cambrige: Cambridge University Press, 1954:495-7 and $198 \mathrm{n}$. 1.

29 Aleshire SB. The Athenian Asklepieion: the people, their dedications, and their inventories. Amsterdam: Gieben, 1989.

30 Thesaurus Cultus et Rituum Antiquorum. Los Angeles: The J. Paul Getty Museum, 2005. IV (henceforth Thes $C R A$ )

31 Lesky A. The Anatomical Votive Terracotta Phenomenon: The Complexities of the Corinthian Connection. In: Georgiadis M, Koltsida A, Muskett G, eds. SOMA 2001 Symposium on Mediterranean Archaeology. (Liverpool, 23-25 February 2001). Oxford: Archaeopress publisher of British Archaeological reports, 2002:193-202.

32 Glinister F. Reconsidering. YCS 2006;33:13.

33 Fabbri F. Votivi anatomici dell'Italia di età medio e tardo-repubblicana e della Grecia di età classica: due manifestazioni cultuali a confronto. Bollettino di archeologia online. Special issue: International Congress of Classical Archaeology: Meeting between cultures in ancient Mediterranean. 2008:22-32 www.archeologia.beniculturali.it/ pages/pubblicazioni.html

34 Livy. History of Rome, $X 47$

35 Pliny the Elder, Natural History, XXIX 16.

36 Rebuffat $D$, Emmanuel D. Contribution à l'identification des divinités de Portonaccio. Latomus:196 20:469-84.

37 Vauthey M, Vauthey P. Les ex-voto anatomiques de la Gaule romaine (Essai sur les maladies et infirmités de nos ancêtres) - Chapitre IV. Revue archéologique du Centre de la France 1983:22:75-81.

38 Curie J, et al. Découverte d'un ex-voto particulier sur le site cultuel d'essarois (Cote d'Or): un cas de polydactylie chez le Gallo-Romains? Revue archeologique de l'Est 2011;60:563-8.

39 Aleshire SB. The Athenian Asclepieion. Amsterdam: Gieben, 1989.

40 Castagnoli F. Lavinium II. I tredici altari. Roma: De Luca:1972-5.

41 Fenelli M. Votivi anatomici. Roma: De Luca, 1975:253-303.

42 Potter T, Wells C. A republican healing-sanctuary at ponte di nona near rome and the classical tradition of votive medicine. Journal of the British Archaeological Association 1985;138 1:23-47

43 Ferrea L, Pinna A, votivo Ideposito. In: Coarelli F, ed. Fregellae. 2. I/ santuario di Esculapio. Roma: Quasar, 1986:89-144.

44 Hanninen ML, et al. 'Traces of Women Devotion in the Sanctuary of Diana at Nemi'. In: Brandt JE, ed. Nemi- Status quo: recent research at Nemi and the Sanctuary of Diana. Roma: L'Erma di Bretschneider, 2000:45-50

45 Comella A. Il materiale votivo tardo di Gravisca. G. Bretschneider: Roma, 1978.

46 Costantini S. Il deposito votivo del santuario campestre di Tessennano'. In: Costantini S, Torelli M, Comella A, eds. Corpus delle stipi votive in Italia, 8, Regio VII, 4, Archaeologica 112 Roma G. Bretschneider, 1995.

47 Comella A. II santuario di Punta della Vipera. I materiali votivi. In: Torelli M, Comella A eds. Corpus delle Stipi Votive in Italia, 13, Regio VII, 6, Archaeologica 131. Roma: G. Bretschneider, 2001.

48 Catucci M, Jannelli L, Sanesi Mastrocinque L. Il deposito dell'Acropoli di Cuma. In: Torelli M, Comella A, eds. Corpus delle Stipi Votive in Italia, 16, Regio I 2. Archeologica 138. Roma: G. Bretschneider, 2002

49 Ammerman R. The Sanctuary of Sancta Venera at Paestum. II: The Votive Offerings. Ann Arbor: University of Michigan Press, 2002

50 Turfa JM. Anatomical votives. ThesCRA 2004;1:359-68.

51 Stieda L. Anatomisch-archäologische Studien. II. Anatomisches über alt-italische Weihgeschenke. Wiesbaden: Bergmann, 1959:75-6 and 56.

52 Scopacasa R. Moulding Cultural change. PBSR 2015;83:1-27.

53 Livy. History of Rome., XXIX 10, 2; XXXIX 9, 4.

54 De Cazanove O. Ex voto anatomici animali in Gallia e in Italia. Fontana F, ed. Sacrum facere. Atti del I Seminario di Archeologia del sacro (Trieste, 17-18 February 2012 Trieste: Editrice Università di Trieste, 2013:23-39.

55 Thesaurus Linguae Graecae. A digital Library of Greek Literature - sub voce $\Sigma \pi \varepsilon ́ \rho \mu \alpha$. Irvine: University of California, 2001. http://www.tlg.uci.edu. 


\section{Original article}

56 Fulgentius. Mythologies, III, 7, 120-122. Whitbread LD, ed. Fulgentius the mythographer. Columbus: Ohio University Press, 1971:91.

57 Langlois P. Fulgentius. In: Reallexikon für Antike und Christentum. Stuttgart: Anton Hiersemann, 1972; VIII:632-61.

58 Lesky E. Embriologie. In: Reallexikon für Antike und Christentum. Stuttgart: Anton Hiersemann, 1959;IV:1228-44.

59 Diels H, Kranz W. Die Fragmente der Vorsokratiker, I-III. Berlin: Weidmann, 1952. Henceforth D-K. Anaxagoras, 59 A 107; Diogenes of Apollonia, D-K 64 B 6; Democritus (D-K 68 A 141); Alcmaeon, D-K 24 A 13; Hippon of Rhegium, D-K 38 A 12.

60 Homer. Odyssey IV:149-50.

61 Pontani F, ed. Scholia Graeca in Odysseam, II scholia ad libros $\gamma-\delta$. Roma: Storia e Letteratura, 2010:227.

62 Wellmann E. Diogenes aus Apollonia. In: Pauly AF, Wissowa G, eds. Real-Encyclopädie der classischen Altertumwissenshaft. Stuttgart: J. B. Metzlerscher Verlag, 1903, V, 1:764-5.

63 Chantraine P. Dictionnaire Étymologique de la Langue Grecque. Histoire des mots sub voce $\Sigma \pi \varepsilon i \rho \omega$. Paris: Klincksieck, 1968.

64 Frisk H. Griechisches Etymologisches Wörterbuch II - sub voce $\Sigma \pi \varepsilon i \rho \omega$. Heidelberg: C. Winter-Universitätsverlag, 1970.

65 D-K 64 B 6

66 Aristotle. Problems. 876:24-32.

67 Lippi D, Conti AA. The soul and the knee. Knee 2009;16:169-70.

68 Loth J. Le mot désignant le genou au sens de génération chez les Celtes, les Germains, les Slaves, les Assyriens. Revue Celtique 1923;40:143-52.
69 Benveniste E. Un emploi du nom du "genou" en vieil-irlandais et en sogdien. Bulletin de la Société de Linguistique de Paris 1927;27:51-3.

70 Meillet A. Lat. genuinus. BSL. 1927;27:54-5

71 Bettini M, Guidorizzi G. II mito di Edipo. Immagini e racconti dalla Grecia a oggi. Torino: Einaudi, 2004:117-8.

72 Hippocrates. $\mathrm{CH}$, On the articulations 53.

73 Aeschylus. Libation Bearers:168-211.

74 Jouanna J. Notes sur la scène de la reconnaissance dans les Choéphores d'Eschyle (v. 205-211) et sa parodie dans l'Electre d'Euripide (v. 532-537). Cahiers du GITA 1997:77-82.

75 Buxton R. Myths and tragedies in their Ancient Greek Contexts. Oxford: Oxford University Press, 2013:93-4.

76 Pindar. Pythian:X 1-12.

77 Bleakley A. Medical Humanities and Medical Education. How the Medical humanities can shape better doctors. London \& NY: Routledge, 2015.

78 Engelhardt von D. Teaching history of medicine in the perspective of "medical humanities". Croat med 1999:40:1-7.

79 Sallares R. The ecology of the ancient Greek world. Ithaca: Cornell University Press, 1991.

80 Mitchell-Boyask R. Plague and theatre in ancient Athens. Lancet 2009:373:374-5.

81 Tallis R. Myths, medicine, and meaning. The Lancet 2006;367:1135-6.

82 Szczeklik A. More on Catharsis. The Lancet 2006;367:1975. 